\title{
ANNA STRODE
}

Latvijas Universitāte, Latvija

\section{ADRESĀTI 17. GS. RİGĀ SACERĒTAJĀ \\ LATİNUU KĀZU DZEJĀ}

\section{İss kopsavilkums}

Okazionālās dzejas rašanos Rīgā 17. gadsimtā sekmēja Eiropas humānisma strāvojumi, kas Livonijā parādījās jau 16. gadsimtā līdz ar baznīcas reformāciju. Šeit dzìvojošie vācu literāti par godu gimenes svētkiem vai nozīmīgiem notikumiem sacerēja dzeju, t. sk. kāzām, sveicot jaunlaulāto pāri. Svinīgajam brīdim veltìto dzeju radi, draugi un kolēgi iespieda nelielās grāmatināas, kurās dažkārt tika ietverti pat vairāki desmiti izvērstu kāzu dzejoḷu.

Rakstā aplūkota 17. gadsimtā Rīgā sacerētā latīṇu kāzu dzeja (carmina nuptialia, epithalamia, hymenaeus), skaidrota tās vieta kāzu kontekstā un analizēti dzejas adresātu (līgavaiṇa un līgavas) pieminēšanas un uzrunāšanas veidi.

Atslēgvārdi: adresāti, līgavainis, līgava, kāzu dzeja, Rīga, 17. gadsimts.

17. gadsimtā okazionālās dzejas sacerēšanu, tās savdabību un tematisko daudzveidību Livonijā sekmē gan vēsturiskie notikumi, kas norisinājās Livonijas teritorijā 16.-17. gadsimtā, gan Eiropas humānisma strāvojumi.

Humānisms ir brīva, atklāta un apzināta cilvēku darbība kultūras jomā, kur prasība pēc ciennas pret indivīdu ir saistīta ar visas cilvēka dabas, viṇa radīto vērtību apstiprināšanu un vēlmi aizstāt hierarhiski organizēto viduslaiku garīgo sistēmu ar individuālismu. Termins humānisms cēlies no latīnu valodas vārda humanitas (cilvēcīgums, cilvēkmīlestība), kas gan apzīmē sociālo tikumu un individuālās izglītības ideālu, gan arī izvirza augstākās cilvēciskās esības normas (Rubenis 2000, 191).

Humānisma ietekmē rakstnieki, kas iepriekš pārsvarā rakstīja par reliǵiskām tēmām, tagad pievēršas daiḷliteratūrai un, koncentrējot uzmanību uz indivīdu, vairāk attēlo personīgās dzivves notikumus.

Lìdz ar humānisma uzplaukumu atdzimst interese par antīko pasauli un literāro mantojumu. Uzmanība tiek pievērsta seno grieḳu un romiešu tekstu jaunatklāšanai un studēšanai, interpretēšanai un ideju 
un vērtību asimilācijai (Mann 2004, 12). Paralēli antīko tekstu izpētei tiek radīts ievērojams apjoms jaunu tekstu - pārṇemot citur Eiropā raksturīgās tendences, līdzịgi kā Vācijā, arī Livonijā dzīvojošie vācu literāti, sacerot okazionālo dzeju, ${ }^{1}$ gimenes svētkos vai nozīmīgos notikumos apsveic gan sabiedrībā pazīstamas personas, gan kolēǵus. Starp šiem apsveikumiem ir arī 17. gadsimtā latīṇu valodā sacerētā kāzu dzeja (carmina nuptialia, epithalamia, hymenaeus), kas ietverta vai nu okazionālās dzejas krājumos ar nosaukumu sylvae/silvae, vai arī iespiesta atsevišķi. Atspoguḷojot vienu no kāzu dzejas aspektiem - dzejas adresātu (līgavas un līgavaiņa) uzrunas un pieminēšanas veidus, rakstā sniegts ieskats 17. gadsimtā Rīgā sacerētajā latīṇu kāzu dzejā.

Latvijas Universitātes Akadēmiskās bibliotēkas Rokrakstu un reto grāmatu nodaḷā atrodas 349 (pavisam 7025 rindas) kāzu dzejoḷi latīṇu valodā - līdz šim netulkoti un maz pètīti. 17. gadsimta sākumā Rīgā tos iespiedis otrais pilsētas tipogrāfs Gerhards Šrēders (Gerhard Schröder, ?-1657). Kāzu dzejas iespieddarbu saturs veidots gan individuāli, gan kolektīvi. Dzejoḷu apjoms svārstās no 2-6 rindiṇām īsākajos dzejoḷos² līdz 160 rindām garākajos, ${ }^{3}$ bet vairākums ir 10-20 rindas. ${ }^{4}$ Dzejoḷu skaits lielā mērā ir atkarīgs no adresāta atpazīstamības. Rīgā 17. gadsimtā vienām kāzām veltīts no 1 līdz 20 vai nedaudz vairāk dažādu autoru dzejoluu. Salīdzinoši tas ir niecīgs skaits pretstatā epitalāmiju kolekcijām, kas sacerētas angḷu karaliskajām g̊imenēm. Piemēram, princeses Elizabetes Stjuartes (Elizabeth Stuart, 1596-1662) un Pfalcas Fridriha (Fridrich Falcký, 1596-1632) kāzām 1613. gadā tika sacerēti 230 epitalāmiji5; Anglijas karala Čārlza I Stjuarta (Charles I, 1600-1649) un Henrietas Marijas (Henriette Marie, 1609-1669) kāzām 1625. gadā sacerēti 129 dzejoḷi; Anglijas karaḷa Čārlza II (Charles II Stuart, 1630-1685) un Bragansas Katrīnas (Catarina de Bragança, 1638-1705) kāzām 1662. gadā - 75 dzejoḷi (Tufte 1973, 4). Tas ir loğiski, jo nav salīdzināms Livonijas un seno angḷu dzimtu dižciltības līmenis un starptautiskā atpazīstamība.

Autori okazionālās dzejas sacerēšanā izmantoja teorētiḳu norādītos

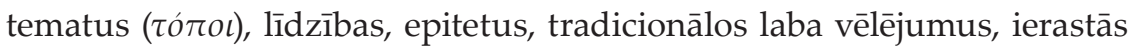
stratēgijas un tehnikas (Greene 1957, 218-219). Viens no nozīmīgākiem teorētiskajiem avotiem bija itāḷu humānista Jūlija Cēzara Skaligera (Julius Caesar Scaliger, 1484-1558) grāmata Septinas poētikas grāmatas (Poetices libri septem, 1561), kurā piedāvāta pārveidota un papildināta grieḳu un romiešu rētoru teorija par kāzu dzejas sacerēšanas pamatprincipiem, kā arī skaidrota kāzu dzejas definīcija: 
Epithalamium carmen igitur est, quo nuptiae celebrantur; a thalamo dictum. Est

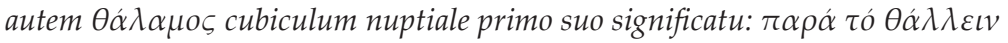
$\alpha \check{\mu} \alpha$, quod est simul genialem vitam agere. (Scaliger 1594, 381)

Epitalāmijs (epithalamium) ir dziesma, kurā tiek cildinātas kāzas; nosaukums

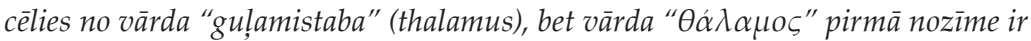

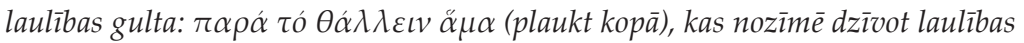
$d z \bar{i} v i{ }^{6}$

Sākotnēji tā, iespējams, bija noteikta veida dziesma, ko dziedāja vai deklamēja pie guḷamistabas durvīm vai pie laulības gultas, bet jau romiešu dzejnieka Katulla (Gaius Valerius Catullus, ap 84. - ap 54. g. p. m. ē.) laikā un vēlāk par epitalāmiju sauca gandrīz ikvienu kāzu dzejoli (Tufte 1970, 3). Viduslaikos galvenā uzmanība tika pievērsta reliǵisku tekstu studēšanai un jaunradei, tāpēc par epitalāmiju tika saukta reliǵiska satura dzeja un proza, kas ar kāzu tēmu saistīta tikai metaforiski. Savukārt, uzplaukstot renesanses humānismam, dzejas autori no jauna pievērsās klasiskajai literatūrai, sacerot epitalāmijus, kas veltīti konkrētām notiekošām kāzām.

Atbilstoši J. C. Skaligera dzejas sacerēšanas pamatprincipiem kāzu dzejolī iekḷaujamas sešas atšḳirīgas komponentes. Vispirms dzejā jārunā par līgavaiņa nodarbošanos un līgavas jūtām:

Verum illius aperte dices studia, curas, celebritates cantionum, ludorum, armorum: virginis gratia facta omnia. Huius autem animum tectis indiciis, conditis suspicionibus innues potius quam profiteberis... Aliquando finges a Venere aut Cupidine vi coactam [..] (Scaliger 1594, 381)

Par līgavaina nodarbošanos, rūpēm, par dziesmu, spēḷu un roku slavu tu runāsi patiesību atklāti: šìs visas [lietas] ir darìtas jaunavas dēḷ. Bet par līgavas jūtām labāk dosi mājienu ar atturīgām norādēm un slēptām nojautām nekā teiksi atklāti. Dažreiz tu iztēlosies, ka [viṇa] ir Veneras vai Kupidona spēka saistīta [..].

Vēsturiski laulības sarunāja vecāki, tādēl līgava par gaidāmo savienību izjuta šaubas un nemieru. Līgavaiṇa labo rakstura īpašību un panākumu cildinājumam vajadzēja līgavu nomierināt un viest vin̄ā pārliecību, ka gaidāmā laulība būs harmoniska un veiksmīga. Antīkajā pasaulē kāzu dzeja tika sacerēta adresātu dzimtajā valodā, bet agrīnajos jaunākajos laikos ${ }^{7}$ - svešvalodā. Nemot vērā līgavaiṇa izglītību, ir skaidrs, ka viņš latīṇu valodā sacerētos veltījumus saprata, turpretī līdz 
līgavai, kas labākajā gadījumā bija ieguvusi pamatizglītìbu, krāšņais vēstijjums nenokḷuva, pat ja kāzu dzejā bija daiḷrunīgi cildināts līgavainis un izteikti laimes paredzējumi.

Pēc līgavaiṇa prasmju un līgavas jūtu atainošanas kāzu dzejā vēlams pievērsties adresātu slavai, laba paredzējumiem, ķircināšanai, vēlējumiem un skubināšanai uz miegu:

Secundo loco explicabuntur laudes utriusque a patria, genere, animi studiis, corporis praestantia. Tertius bene ominabitur. Quarti lascivia lususque est totius alterutrum aut utrumque blande appellando, modestius virginem, haud modestissime tamen obiciendo quaedam, puta proelii futuri metum, victoriam, e lacrimis risum, e spe laetitiam certam. Quinto loco sobolem pollicetur, vota facit, vaticinatur. Postrema pars exhortationem continet ad somnum, ac somnum quidem aliis, illis vero vigiliam. (Scaliger 1594, 381-382)

Pēc tam tiks izskaidrota abu slava tēvijā: izcelsmes, prāta dedzības [un] k̦ermeņa pārākuma dēḷ. Trešajā [daḷā] labi paredz. Visas ceturtās [daļas pamatā] ir koḳetēšana un k̦ircināšana, uzrunājot vienu vai abus valdzinoši - jaunavu piesardzīgāk, nekādā ziņā nepārkāpjot pieklājības [normas], tā sakot, paturi [prātā] bailes no nākamās cīnas, uzvaru, pēc asarām smieklus, pēc cerības patieso lìksmību. Piektajā daḷā sola pēcnācējus, izsaka vēlējumus, paredz [nākotni].

Pēdèjā daḷa ietver skubināšanu uz miegu, taču miegu citiem, bet vin̨iem (laulātajiem) nomodu.

Sekojot J. C. Skaligera grāmatā Poetices libri septem ietvertajiem dzejas sacerēšanas pamatprincipiem, veidojas šādas kāzu dzejas komponentes: 1) personīgās informācijas paušana par līgavaini, līgavas jūtu pieminēšana (atturīgi); 2) līgavas un līgavaiṇa cildināšana; 3) laba pareǵojumi; 4) līgavas un līgavaiṇa uzrunāšana; 5) vēlējumu un nākotnes paredzējumu izteikšana; 6) skubināšana uz miegu. Par to, ka šì teorija bijusi zināma Rīgā, liecina šāda dzejas struktūras ievērošana, piemēram, Rīgas Akadēmiskās ǵimnāzijas log̣ikas un metafizikas profesora Johana Struborga (Johann Struborgius, ?-1645) dzejolis par Ēho (Echo).

Dzejoḷa pirmajā daḷā vēstīts par dzejoḷa sacerēšanas iemeslu - "saderināšanās saišu" svinēšanu - un pieminēts gan svinīgais noskaṇojums Rīgā, gan konkrētais līgavainis ar līgavu. Pēc tam autors pievēršas adresātu cildināšanai un abu vienlīdzības atzīšanai. Dzejoḷa noslēgumā izteikta lūgšana, lai attiecībās valdītu savstarpēja mīla, nebūtu strīdu un bēdu un lai sirdis tiktu sasietas ar pastāvīgu mezglu, t. i., lai jaunlaulāto savienība būtu pastāvīga/ilgstoša. Visbeidzot, pāris skubināts uz miegu. 


\section{Ēho (Atbalss)}

Mēs svinam saderināšanās liesmas, saderināšanās saites, Ēho (Atbalss), atnes vārdus atpakal, kurus es paziņoju, E. paziņoju.

Apreibusī pilsēta Rīga jau pietiekami aplaudē ar svinīgu plaudēšanu;

Lūk, jaunas runas: [vai] tur nav kliedzieni? E. mīla.

Kāda mīla? Vai tad Junona viņam atkal saites sien?

Vai tad viṇam netiek dota jaunava aptraipīta? E. Likumīga!

Skat Pēterim Katrīna tiek dota! Tādēl padodies bildinātajai:

Šìs liesmas rada Kitēriete, E. Dieve.

Vai Atlanta Hipomeneju neiekvēlināja? Vai ko?

Vai lai es atceros Alkidu? Ir uguns-kvēle mīlā. E. kavēšanās.

Līgavainim laulībā tiek dota ievērojama jaunava, atvase, \} Līgavas

Hēbe, Tetīda, Gnosa (gudrība), mirdzošā najāda, E. tu saki.\}

Un tev, Lìgava, tiek dots tas, kurš ar zināšanu zal,o,

Vienlīdzības

atzišana

Un bez Tikuma ceḷa neiet, E. viņš tuvojas.

Godā jūs esat vienādi! Izcils vīrs, jaunavas cien̄igs!

Jaunava vīram: jaunava ar k̦ermeni pievilcīga, E. zīme. \}

Lūgšana, vēlējums

(Dari tagad, Kristus, lai dvēseles sadedzinātu abpusējas liesmas!

Lìgavaiņa

cildināšana

Ligavas

cildināšana

Lai nelāgs strīds ar bēdām iznīktu, E. pazustu.

Panāc, lai sirdis tagad tiktu sasietas ar pastāvīgu mezglu!

Ejiet: stāv ar uguni pie guḷamistabas sliekšn,a, E. Himenejs.

Skubināšana

uz miegu

J. C. Skaligers dzejas autorus rosina uzmanīties no pārlieku uzkrītošas līgavas cildināšanas. Atbilstoši šim ieteikumam 17. gadsimtā sacerētā kāzu dzeja līgavainim veltīta vairāk nekā līgavai vai abiem laulātajiem. Dzejā lietoti gan darbības vārdi vienskaiț̣a otrajā personā, gan personas vietniekvārds tu (tu). Tomēr šāds izteiksmes veids noved līdz paradoksam - dzejas autori raksta par notiekošā saistību ar līgavaini (piem., ka viņam tiek dota šḳīsta līgava), nevis apraksta paša līgavaiņa raksturiezìmes un slavējamos darbus. Lìdz ar to kāzu dzejā norāžu par līgavu (viṇas raksturojumu un izskatu) ir vairāk nekā par līgavaini, kas ir pretēji J. C. Skaligera un seno rētoru ${ }^{8}$ norādījumiem. Spilgts piemērs ir rīdzinieka Henrija Hagēna (Henricus Hagens) J. Flīgelam sacerētais kāzu dzejolis, kurā uzmanība vērsta galvenokārt uz līgavu. Dzejol̄i lieliem burtiem izcelts līgavas vārds Anna (deminutīvā Annula), kā arī sniegts viņas raksturojums:

En, cognate, tibi tua ducitur ANNULA, Chare:

ANNULA permultis Sponsa petita Procis;

ANNULA Casta, sui palmaris adorea sexus,

ANNULA Virginei, faxque decusque, Chori:

ANNULA laudandae Pietatis, Amoris honesti,

ANNULA Virtutum plurima puncta ferens. [..]

(Acclamationes votivae .. 1636, [18])

CXL 


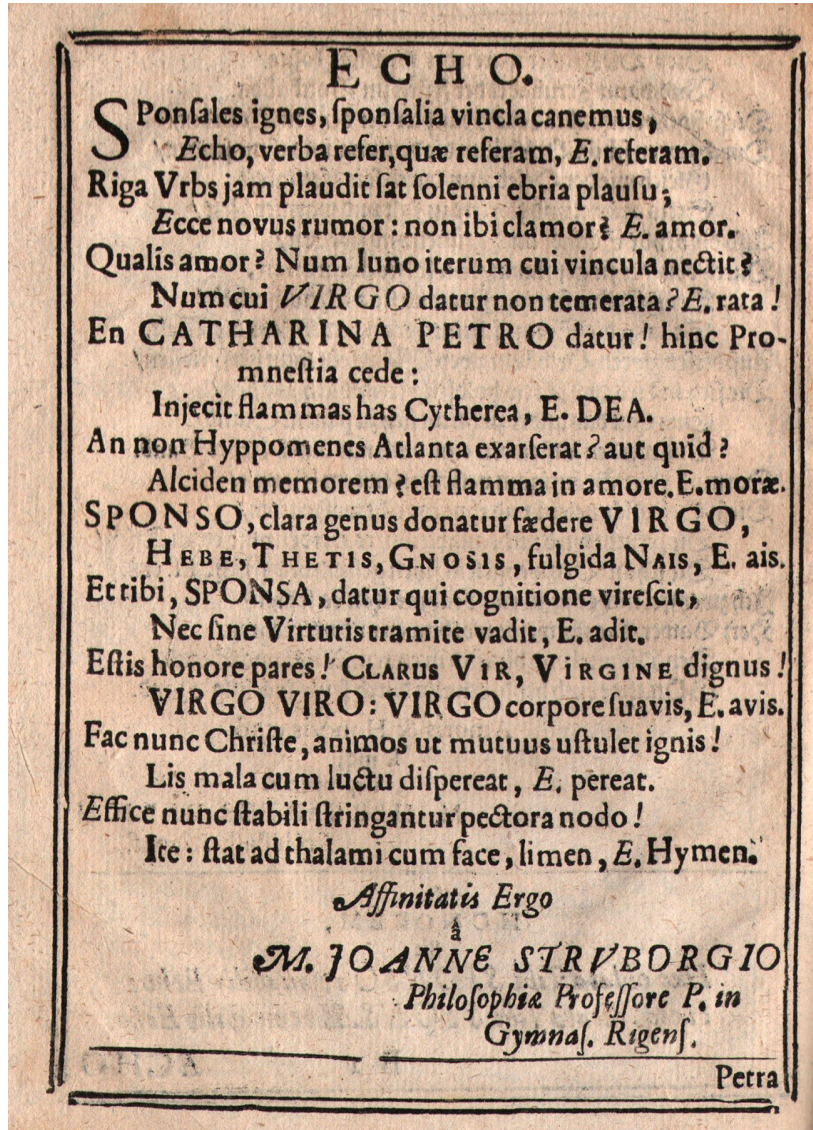

Pētera Bauera (Petrus Bauer, 1606-1657) un Katrīnas (Catharina Meiners) kāzām veltītā J. Struborga dzeja (Epithalamia honori .. 1636, [11])

Skat, tev tiek vesta tava ANNINA, ${ }^{9}$ dārgais tuviniek: ANNINA - no loti daudziem dižciltīigiem kārota līgava;

Šḳistā ANNINA, sava dzimuma cienīgā balva, ANNIN,A, jaunavas kora rota un lāpa:

Cildināmas dievbijības, godīgas mīlestības ANNINA

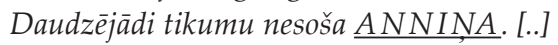

Analizējot dzejas adresātu uzrunas un pieminēšanas veidus, izcel̦ama līgavas un līgavaiņa uzruna pēc adresāta lomas, personvārda (vārda un uzvārda), dzimuma, nodarbošanās, dzejas autora un adresāta savstarpējās saistības. 
Atbilstoši kāzu dzejas būtībai, uzrunājot adresātu pēc tā lomas un runājot par vīrieti, izmantota leksēma sponsus (līgavainis), par sievieti sponsa (līgava). Lai atspoguḷotu līgavas sievišķību un tās maigo dabu, lietots deminutīvs sponsula (līgavina). Atsevišḳos gadījumos sastopamas leksēmas maritus (vīrs / precējies vīrietis) un uxor (sieva). Piemēram, livonietis Bernards Rams (Bernardus Ramm) dzejā izklāsta līdzību - tāpat kā ticīgam vīram tiek dota mīlama sieva (uxor), tā arī līgavainim (adresātam) tiek dota patīkama līgava:

Qui fidit Domino, datur uxor amibilis ipsi,

Hinc \& SPONSE datur, blanda puella, tibi,

Firma aetate vigens, clarisque parentibus orta;

Inprimis niveae simplicitatis amans.

(Tragemata melica .. 1637, [8])

Kurš tic Kungam (Dievam), tam tiek dota mìlama sieva,

Tādēl arì tev, Lìgavaini, tiek dota laipna meitene,

Ziedoša spēka pilna gados un dzimusi no ievērojamiem vecākiem;

Visvairāk mìloša sniegbaltu (tìru) vienkāršǐbu.

Savukārt leksēmas pater (tēvs) un mater (māte) lietotas, domājot par jaunā pāra statusu, ǵimenē ienākot pēcnācējiem. Atbilstoši okazionālās dzejas sacerēšanas tradīcijai 17. gadsimta latīṇu kāzu dzejā līgava un līgavainis ir idealizēti kā personas, kurām piemīt vislabākās iespējamās īpašības - viṇi tiek cildināti kā visgudrākie, godājamākie, spožākie, skaistākie un vistikumīgāk dzīvojošie cilvēki. Tas pats tiek sagaidīts arī no viṇu pēcnācējiem. Līdzīgi kā citi kāzu dzejas autori, ${ }^{10}$ arī Rīgas Jēzus baznīcas mācītājs Johans Brēmers (Johann Bremer) adresātiem novēl pēcnācējus, kuri pārmantotu viṇu tikumus:

Numerosam cernite prolem, quae Matris referat virtutes, atq; Paterna

Dona repraesentet, virtutibus aemula pulcris.

(Epithalamia in festivam .. 1636, [15])

Raugiet pēc neskaitāmiem pēcnācējiem,

kuri mātes tikumus nestu un tễva

veltes parādìtu, kas pielìdzināmas cēliem tikumiem.

Minētajā piemērā redzams novēlējums gādāt pēcnācējus, kas ir viens no galvenajiem kopdzīves mērḳiem dzimtas turpināšanai. Pētnieks 
Tomass Manks (Thomas Munck) noskaidrojis, ka Eiropā gimenēs 17. gadsimtā katrai sievietei dzima vidēji 4-5 bērni (Munck 2005, 111), kas, ņemot vērā lielo mirstîbu epidēmiju dēḷ, pēc zināmās statistikas (Plantation b.g., 1) reizēm bija nepietiekami. Ģimenes, kas nevarēja radīt savus pēcnācējus, pieṇēma audžubērnus vai izmantoja tuvu stāvošu personu kā surogātvecāku palīizību.

Neskatoties uz to, ka adresātu personvārdi norādīti iespieddarba titullapā, tos atkārtoti iekḷauj arī dzejas tekstos, bet ne obligāti. Uzrunājot līgavaini, tiek lietots viṇa personvārds, turpretī līgavas personvārdu pārsvarā lieto brīžos, kad viṇa tiek raksturota līgavainim. Iespēju robežās dzejas autori pievēršas personvārdu nozīmei: līdzās līgavas vārdam Klāra dzejā ietverts īpašības vārds clarus, - $a$, -um ('spožs, spoža'), bet līgavainim Pēterim veltītajās dzejas rindās pieminēts lietvārds petra, -ae ('klints'). Rīdzinieka Johana Maiera (Johannes Maier) dzejolī, kurā viņš iejuties līgavaiṇa Pētera tēlā, vēstīts par līgavaiṇa vēlmi turēties pie līgavas sāna tik cieši, kā neizkustināma klints turas virs kalniem, t. i., dzejas rindās atainota vēlme ilgstoši saglabāt ciešas attiecības:

Ceu Petra immobilis super altis montibus haeret; Haerebo lateri sic CATHARINA tuo. (Epithalamia quibus .. 1633, [4-5])

Tāpat kā neizkustināma klints turas virs augstākajiem kalniem; Tā, Katrīna, es turēšos pie tava sāna.

Ja personvārda nozīme saistāma ar negatīvu īpašìbu, autori tiecas paskaidrot, ka adresātam nepiemīt personvārda etimologijā ietvertais raksturojums. Piemēram, līgavas vārds Barbara latīṇu valodā barbarus, -a, -um nozīmē 'necivilizēta, neizglītota, rupja, barbariska'. Lai parādītu, ka mācītāja Johana Bērdinga (Johann Börding) līgava Barbara neatbilst sava vārda latīniskajai nozīmei, Vidzemes superintendenta Hermaṇa Samsona (Hermann Samson, 1579-1643) dēls Bruno (Bruno Samsonius) ietver savu attieksmi gan dzejoḷa nosaukumā Par vislieliskākās līgavas vārdu (De nomine sponsae lectissimae), gan dzejas rindās:

Tu qui barbariem fugis,

Bördingi, studiis deditus optimis,

Quae nunc mens-animi Tibi?

Quid nunc BARBARA quid Virgo Tibi placet?

Verùm BARBARA nomine

Non est barbaricis barbara moribus [..]

(Aves Cypriae .. 1638, [15]) 
Tu, kurš vairies no izglītības trūkuma, Bordingij, kurš nodevies visaugstākajām zinībām,

Kāds tev tagad gara prāts?

Ko, tagad Barbara, tagad jaunava tev patīk?

Patiešām, [tā, kas] Barbara vārdā,

Nav svešiniece ar barbaru tikumiem. [..]

Līgavaiṇa un līgavas uzrunāšana pēc dzimuma kāzu dzejā ir pašsaprotama, jo atbilstoši baznīcas likumiem laulības tiek noslēgtas starp sievieti un vīrieti. Uzrunājot līgavaini, lietotas leksēmas vir (vīrs) vai juvenis (jauns vīrs, jauneklis). Savukārt līgavu piemin ar leksēmām puella (meitene), juvencula (jauna meitene), virgo (jaunava, jauna sieviete) un virago (varonīga sieviete). Šāds leksēmu īpatsvars liecina, ka līgavas ir samērā jaunas, kamēr līgavaiṇi ir nobrieduši vai arī par tādiem tiek uzskatīti. Salīdzinot leksikonos ${ }^{11}$ atrodamās biogrāfiskās ziṇas ar iespieddarbos norādīto kāzu gadu, noskaidrots, ka Livonijā daḷa vīriešu par līgavaiṇiem kḷuva vecumā ap 30 gadiem. Piemēram, Rīgas birǵermeistars J. Flīgels aprecēja līgavu Annu 1636. gadā, kad viņam bija 33 gadi, tajā pašā gadā 30 gadu vecumā P. Bauers aprecēja līgavu Katrīnu. Rietumeiropas ǵimenēm raksturīgs, ka pirmā laulība tika noslēgta diezgan vēlu - sievietēm vidēji pēc 25 gadiem, vīriešiem pēc 28 gadiem. Ja laulības, sekojot tradīcijai, tika noslēgtas šajā vecumā, starp vīru un sievu bija 2-3 gadu starpība. Attiecīgi, ja laulības kādu iemeslu dẹḷ tika noslēgtas vēlāk (piem., atkārtotas laulības gadījumā, ko bija pien,emts noslēgt jau 15,5 mēnešus pēc dzīvesbiedres zaudēšanas vīriešiem, pēc 39 mēnešiem - sievietēm), par dzīvesbiedru kḷuva persona, kas bija ievērojami jaunāka. Iemesls tam gluži vienkāršs - jo vecāka persona, jo mazāk potenciālo tāda paša vecuma partneru un lielāks daudzums jaunāku potenciālo dzīvesbiedru (Fauve-Chamoux 2001, 224). Sociālo faktoru ietekmē dzīvesbiedra izvēle bija visai ierobežota, tāpēc nācās slēgt laulības ar personu, pret kuru nebija siltu jūtu.

Uzruna pēc nodarbošanās (atbilstoši vēsturiskajai situācijai) vērojama tikai, vēršoties pie līgavaiṇa. Dzejā lietotas profesiju apzīmējošas leksēmas magister (skolotājs, profesors) un pastor (mācītājs). Adresātu (līgavaiņa un līgavas tēva) nodarbošanās tiek norādīta dzejas iespieddarbu titullapās. Pēc titullapu izpētes kḷūst skaidrs, ka cilvēki slēdz laulības tikai ar sev līdzvērtīgiem, t. i., tādiem, kuri nāk no viena sociālā slānna. Piemēram, Rīgas Doma baznīcas mācītājs Johans de Grāvens (Johannes de Graven) 1632. gadā aprecēja Urzulu (Ursula Rigemann), Rīgas Svētā 
Jāṇa Evaṇgèēiski luteriskās baznīcas mācītāja Kaspara Rīgemana (Caspar Rigemann) meitu (Carmina ad .. 1632, [1]).

Dzejas autora un adresāta savstarpējā saistība dzejoḷos atklājas, uzrunājot līgavaini ar leksēmu amicus (draugs), līgavu - ar leksēmu soror (māsa). Leksēmas soror lietojums nav stilistisks paṇēmiens draudzīgas attieksmes izrādīšanai, bet norāda uz faktisko radniecību. Piemēram, 1643. gadā mācītāja Pētera Arvīda Guthemija (Petrus Arvid Guthemius, ?-1644) meitai Ģertrūdei (Gerdruda) dzeju velta viṇas brāḷi Johans (Johann Petri Guthemius) un Jēkabs (Iacobus Petri Guthemius). Johans māsai velta divas dzejas rindas, uzrunājot viṇu kā laipnu māsu (alma soror), bet Jēkabs māsai velta 17 dzejas rindas, tajās vairākkārt vaicājot Saki man,

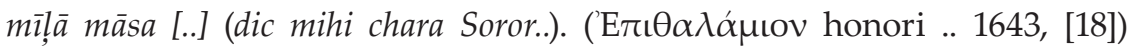
Šādos radniecības gadījumos līgava, atšķirībā no citu autoru kāzu dzejoliem, ir uzrunāta emocionālāk.

Uzrunājot vai apzīmējot adresātus kādā no aprakstītajiem pieciem veidiem, līgavas un līgavaiṇa labāko īpašību atspoguḷošanai tiek lietoti vairāk nekā 20 epitetu, ${ }^{12}$ lielākoties tie ir sinonīmi.

Līgavainis latīnu kāzu dzejā attēlots kā spēcīgs (strenuus), labs (bonus), godājams (honoratus), mācīts (doctus), izcils (praestans) vīrs (vir); visievērojamākais (clarissimus) vīrs savā profesijā. Viņš aprakstīts kā pirmškirīịs (praeclarus) un cienījams (reverendus) maǵistrs (magister). Visizvērstākā epitetu grupa pavada leksēmu līgavainis (sponsus). Neatkārtojot iepriekš minētos epitetus, var pieminēt tādus īpašības vārdus kā mịlots vai dārgs (charus), cienījams (colendus) un laimīgs (felix). Lietoti arī epiteti novus (jauns) un novellus (jauniņais), bet saistībā ar jauno statusu, nevis līgavaiņa vecumu.

Runājot par līgavu, tiek izceltas citas iezīmes - līgava var tikt raksturota kā šḳista (casta) un laipna (blanda) meitene (puella) vai arī kā skaista (formosa), mīlīga (venusta), kautrīga (pudica) jaunava (virgo). Autori mēdz paust domu, ka līgava ir Dieva dota, t. i., Dieva dāvana (Dei donum) - vislieliskākā līgava (lectissima sponsa).

Reizēm viṇa attēlota kā drosmīga sieviete no dižciltīgas dzimtas (generosa virago). Antīkajā literatūrā jaunas sievietes apzīmējums ar lietvārdu (virago) saistās ar sieviešu agresivitāti, tāpēc vārdam piemīt negatīva konotācija. Tādējādi kāzu dzejā tā varētu būt norāde uz nākamās sievas valdonīgumu un tieksmi dominēt ǵimenē. Vēstures profesore Sandra Kavallo (Sandra Cavallo) norāda, ka sievietes ikdienas uzdevums bija rūpes par mājsaimniecības darbiem, kas saistīti ar cilvēka 
ķermeni - dzimšanu, ēdienu, veselību, nāvi -, un tas ievērojami mazināja vīrieša ietekmi, kad mājas intīmajā vidē viņš saskārās ar fizisku ievainojamību un palāāās uz sievu savu pamatvajadzību piepildīšanai (Cavallo 2010, 24).

Līgavas aprakstā lietota arī leksēma nimfa (Nympha), piemēram, advokāta Mihaēla Hornunga (Michael Hornung) sieva Klāra (Clara Schröder) aprakstìta kā casta, pia, pulcherrima Nympha (šķīsta, dievbij̄̄ga un l̦oti skaista Nimfa) (Epithalamia in solennes .. 1636, 16). Šeit leksēma nimfa

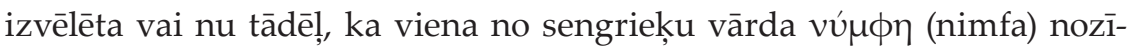
mēm ir 'līgava', vai arī tādēl, ka nimfas grieḳu mitologijā ir attēlotas kā skaistas jaunavas precību gados. Dominējošais leksēmu sponsa (līgava) pavadošais epitets ir pudica (kautrīga), ko autori regulāri iekḷauj izvērstos līgavas aprakstos galvenokārt saistībā ar līgavas sarkšanu.

Kā redzams, līgava un līgavainis tiek attēloti kā ideālas personas ar atškirīgām izceltām raksturiezīmēm, bet abi ir cienījami (dignus, $-a$ ) un ar labu reputāciju (venerandus, $-a$ ). 17. gadsimtā bija izplatīts viedoklis, ka mīlestība nāk pēc kāzām, tādēḷ dzejā autori vairāk runā par pieķeršanos un simpātijām nekā par mīlu. Lìgava un līgavainis ir aprakstīti kā viens otram dārgi un mīḷi (carus, -a). Un svarīgākais - viṇus atzīst par līdzvērtīgiem (par, paris). S. Kavallo izpētījusi, ka agrīno jauno laiku rakstu avotos plaši aprakstīts ideālais patriarhālas ǵimenes modelis. Tomēr, lai arì tekstos izcelta vīra autoritāte pār sievu, bērniem un kalpiem, tekstos iedrošināts laulībā saglabāt partnerību un intimitāti (Cavallo 2010, 3).

Atsevišḳi kāzu dzejoḷi sarakstīti pirmajā personā, tiem piešḳirti nosaukumi Sponsus ad sponsam (Lìgavainis ligavai) vai Sponsa ad sponsum (Lìgava lìgavainim). Šādi dzejoḷi sarakstīti savstarpējās uzrunas formā tā, it kā to viens otram būtu sacerējuši līgavainis un līgava. Uzskatāms piemērs tam ir kurzemnieka Georgija Gosēna (Georgius Gosens) dzejolis, kurš sacerēts, iztēlojoties, ko līgavainis P. Bauers varētu teikt līgavai Katrīnai:

Chara puella veni, propera mea Amasia dulcis;

Cor totum languet, chara puella veni! [..]

(Tiaras sacerdotalis .. 1636, [29])

Nāc, mīḷa meitene, pasteidzies, mana saldā mīlotōa; visa [mana] sirds vīst, nāc, mì̄ la meitene! [..] 
Katrīna uz to varētu atbildēt šādiem vārdiem:

En adsum, Charitum decus, o mi Sponse novelle:

En adsum praesto Lux mea, vita mea.

(Tiaras sacerdotalis .. 1636, [30])

Redzi, es esmu šeit, Grāciju spožums, ak, mans jaunais līgavaini:

Redzi, es esmu šeit tuvu, mana gaisma, mana dzīve.

Jaunlaulāto lomās dzejas autors var atḷauties būt mazāk piesardzīgs un neievērot J. C. Skaligera aicinājumu dzejā atklāti nerunāt par līgavu un viṇas jūtām, tādējādi tiekot pasargāts no nejaušām neveiklībām (t. i., nepārkāpt sabiedrībā pieṇemtās normas, publiskā vidē būt atturīgam personīgo jūtu paušanā), par ko varētu pārmest, ja viņš runātu savā vārdā.

Nevienā no aplūkotajiem dzejoḷiem nav attēlotas adresātu negatīvās īpašības vai rakstura iezīmes, kuras būtu jāmaina. Tas l̦auj secināt, ka cildinātās personas attēlotas kā ideālas - adresāti ir tikumīgi, izglītoti, dvēseliski tīri un laimīgi. Savukārt, aplūkojot dzejas struktūru un adresāta uzrunāšanas un pieminēšanas veidus, secināms, ka vairums autoru tiecas sekot J. C. Skaligera norādījumiem un dzejas sacerēšanā izmanto vismaz kādu no sešām ieteicamajām komponentēm. Daḷa norādījumu vai nu apzināti, vai nejauši - trūkst (piem., līgavai pievērsta lielāka uzmanība, nekā ieteicams), parādot radošāku pieeju autora ieceru îstenošanā.

Aplūkotie piemēri ir tikai niecīga daḷa no bagātīgā netulkoto un nepētīto latīnu valodas tekstu apjoma, kas atrodas Latvijas Universitātes Akadēmiskajā bibliotēkā.

\section{ATSAUCES}

1 Okazionālā dzeja atzīmē un cildina īpašus dzīves notikumus - kāzas, nāvi, dzimšanu, jubileju, zinātniskā grāda iegūšanu, grāmatas publikāciju, ceḷojuma sākumu u. c. notikumus - estētiski paceltā vai pompozā valodā (Kühlmann 2007, 287).

271 no pētāmajiem 349 dzejoḷiem (jeb 71/349).

$2 / 349$.

$170 / 349$.

Rakstā, apzīmējot kāzu dzeju, tiks lietots termins epitalāmijs (vīr. dz.), nevis Svešvārdu

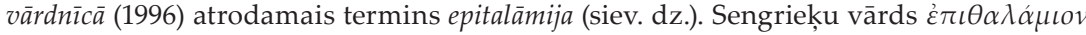
ir nekatrā dzimtē, kas teorētiski piẹ̦auj šì termina lietojumu gan sieviešu, gan vīriešu dzimtē, tomēr pēc izcelsmes termins radies no priedēkḷa غ̇ंí (pieprasa akuzatīvu) un

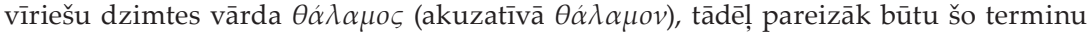
atveidot vīriešu dzimtē. 
6 Šeit un turpmāk tekstu fragmenti doti raksta autores tulkojumā.

7 Agrīnie jaunie laiki (saukti arī jaunie laiki) - Eiropas vēstures periods starp vēlīnajiem viduslaikiem un jaunākajiem laikiem.

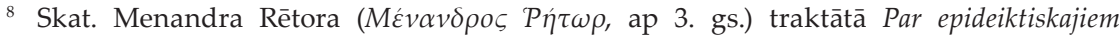

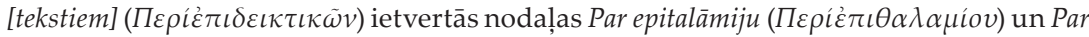

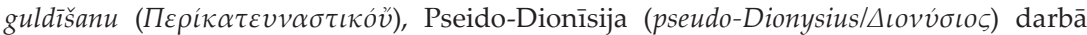

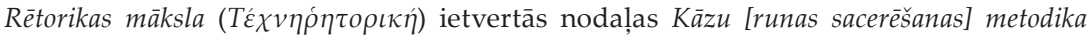

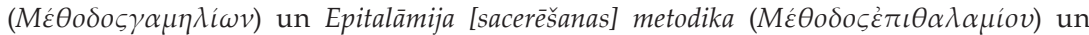

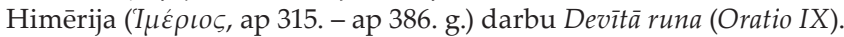

9 Šeit un turpmāk rakstā autores pasvītrojumi dzejas piemēros.

10 To skaitā, piemēram, arī Konrads Bečens (Conradt Betchen), kurš sēlpilieša Nikolaja Hanenfelda un Dorotejas kāzām veltītā dzejolī novēl radīt pēcnācēju, kurš mātes un tễva talantu nestu ([..] gignite prolem I quae genium matris fert geniumque patris). Skat. Faustae acclamationes .. 1639, 4.

11 1) Gottzmann, C. L., Hörner, P. Lexikon der deutschsprachigen Literatur des Baltikums und St. Petersburgs: Vom Mittelalter bis zur Gegenwar. Berlin: Walter de Gruyter, 2007; 2) Liliencron, R. Fr. von, Wegele, Fr. X. von, Bettelheim, A. Allgemeine Deutsche Biographie, band 1-3. Leipzig: Duncker u. Humblot, 1875-1876; 3) Recke, J. F. von, Napiersky, K. E. Allgemeines Schriftsteller- und Gelehrten-Lexicon der Provinzen Livland, Esthland und Kurland, band 1-4. Mitau : Steffenhagen, 1827-1832.

12 Attiecībā uz līgavaini lietoti tādi īpašības vārdi kā: amabilis, bonus, carus/charus, clarus, colendus, dignus, doctus, honoris, novus, praeclarus, praestans, strenuus, venerandus, verendus utt. Attiecībā uz līgavu: alma, amabilis, blanda, cara, casta, digna, formosa, generosa, honesta, lecta, morata, pia, pudica, pulchra, veneranda, venusta utt.

\section{AVOTI}

1. Acclamationes votivae sacris nuptiarum viri clarissimi et consultissimi Domini Johannis Flugelii regij dicasterij aulici Dorpatensis nominati assessoris et officialis regij sponsi, cum nobilissima, lectissimaque virgine Anna, nobilissimi et consultissimi viri Dn. Joachimi Welling collegij majoris hujus civitatis denati senioris relicta filia sponsa. Riga : Typis Schröderianis, 1636.

2. Aves Cypriae sancto amori et illibato Hymeneo viri reverendâ dignitate, dignâ eruditione, eruditâ virtutum eminentiâ praestantissimi, ornatissimi Dn. Johannis Bördingi, Pastoris in Oleckt et Schaddingen vigilantissimi; sponsi et lectissimae, insignique virtutum laudumque ornamento decoratissimae virginias Barbarae reverendi, clarissimi ac doctissimi viri Dni Iohannis Beckers b.m. pastoris templi cathedralis in Livonum metropoli Rigâ meritissimi filiae relictae, sponsae: dictatae gratulationis ergò à fautoribus, amicis, affinibus, ad d. Solennitatis nuptialis 26. februarij. Riga : Apud Gerhardum Schröder, 1638.

3. Carmina ad nuptias, in honorem reverendi et clarissimi viri Dn. M. Johannis de Graven, pastoris in Aede cathedrali apud Rigenses inclytos dexterrimi, ad secunda vota transeuntis cum nobili lectissimaque virgine Ursula, reverendi et eximii viri Dn. Caspari Rigemanni, vigilantissimi quondam ad D. Johannis ibidem pastoris filia: exhibita ab amicis in Prandio, quod solemniter prandebant postridie Dominicae invocavit, anno gratiae 1632. [Riga] : Excudebat Gerhardus Schröder, 1632.

4. Epithalamia honori nuptiarum, reverendi et doctissimi viri, Dni. M. Petri Baveri ecclesiast. sponsi, et lectissimae, pudicissimaeque virginis Catharinae, viri clarissimi, amplissimi et consultissimi Dni Hermanni Meiners praefecti mercaturae, subpraetoris, et senatoris civitatis Rigensis meritissimi filiae, sponsae Rigae, Deo dante, feliciter celebrandarum 5. Non. Octobr. Anni 1636. scripta à fautoribus, collegis, et amicis. Rigae : Typis Gerhardi Schröder, 1636. 
5. Epithalamia in festivam nuptiarum solennitatem clarissimi ac doctissimi viri Dn. Christophori Rigemanni, sponsi, et lectissimae pudicissimaeque virginis Helenae, spectabilis ac honesti viri Dn. Everhardi Ringenberg, civitatis Rigensis collegij majoris senioris meritissimi filiae, sponsae. Non tam moris, quam amoris faustique ominis ergò scripta, exhibita et decantata, â popularibus et amicis mense August. die 29. Anno 1636. Rigae Livonum : Typis Gerhardi Schröder, 1636.

6. Epithalamia in solennes nuptias clarissimi, consultissimi viri D. Michaelis Hornungk, regij judicij provincialis districtus Rigensis Assessoris, fiscique advocati dignissimi, sponsi ut et lectissimae, pudicissimaeque virginis Clarae Schröder, spectabilis et honesti viri D. Reinholdi Schröders, civitatis Rigensis collegij majoris senioris meritissimi filiae sponsae splendido ritu, pompa celebri 15. Iulij Rigae celebrandas; Lusa, Anno 1636. Rigae : Typis Schröderianis, 1636.

7. Epithalamia quibus viro nobili, politissimo ac eruditissimo Dno. Petro Antonii, Judicij castrensis Regij assessori dignissimo, sponso, nec non nobili, lectissimae edecumataeque virtutis virgini Catharinae Stopiae sponsae, viri nobilis ac integerrimi Dni Zachariae Stopii, haereditarij in Segelhoff honestissimae filiae. Rigae : Typis Gerhardi Schröder, 1633.

8. 'E $\iota \bullet \alpha \lambda \alpha \alpha \mu \iota v$ honori nuptiarum viri clarissimi Dn. M. Iohannis Georgii Gezelii Wesmanniâ Sueci, Graecae et orientalium lingvarum in inclyta Academia Gustaviana, quae est Dorpati Livonorum ad Embeccam, profess, publici, sponsi. Nec non lectissimae pudicissimaeque virginis Gerdrudae Gutheim, viri plurimum reverendi Dn. Petri Arvidi Guthemii, pastoris ad Aedem S. Jacobi vigilantissimi, districtus Rigensis praepositi, nec non Proto-sijnedrij, quod est Dorpati, assessoris dignissimi, filiae sponsae. Rigae Livonum : Literis Gerhardi Schröderi, 1643.

9. Faustae acclamationes nuptiarum solennitatibus viri reverendi et clarissimi Dn. M. Nicolai Hanenfeldt verbi divini apud Seelburgenses praeconis vigilantissimi, praefecturarumque, Seelburgensis et Duneburgensis, Praepositi industrij, sponsi, quas ad VI. eidus septembris anni a nato Christo 1639. Seelburgi cum lectissima virgine Anna Dorothea viri admodum reverendi et clarissimi Dn. Pauli Einhorn, ducatuum Curlandiae et Semgalliae generalis superintendentis filia, sponsa facere constituit: facta ab amicis et fautoribus. Rigae : Typis Schröderianis, 1639.

10. Tiaras sacerdotalis sacerdotalis nuptiis auspicatissimis reverendi et doctissimi viri Dni. M. Petri Baueri ecclesiastae sponsi, ut et lectissimae, pudicissimaeque virginis Catharinae, viri clarissimi, amplissimi et consultissimi Dni Hermanni Meiners praefecti mercaturae, subpraetoris, et senatoris hujus Urbis inclytae meritissimi filiae, sponsae, Rigae Livonum 3. Octob. Celebraris Anno nati hominis Dei 1636. Rigae : Typis Gerhardi Schröder, 1636.

11. Tragemata melica ad epulas nuptiales auspicatissimas viri-juvenis nobilissimi ac integerrimi Dni. Christiani Zimmermanni, patritij Rigensis primarij, sponsi, et virginis elegantissimae et edecumatae Annae, praestantissimi et integerrimi viri Dni Gerhardi Maneken, collegij majoris senioris et civis Rigensis eximij filiae, sponsae, transmissa ab amicis et affinibus d. 6. Februar. Rigae : Typis Schröderianis, 1637.

\section{LITERATŪRA}

1. Cavallo, Sandra. Evangelisti, Silvia. Introduction. A Cultural History of Childhood and Familyin the Early Modern Age. Vol. 3. S. Cavallo, S. Evangelisti (eds.). Oxford; New York: Berg, 2010, 1-32.

2. Cavallo, Sandra. Family relationships. A Cultural History of Childhood and Family. Vol. 3. In the early modern age. S. Cavallo, S. Evangelisti (eds.). Oxford; New York : Berg, 2010, 15-32.

3. Fauve-Chamoux, Antounette. Marriage, Widowhood, and Divorce. Family Life in Early Modern Times, 1500-1789. D. I. Kertzer, M. Barbagli (eds.). New Haven; London : Yale University Press, 2001, 221-256.

4. Greene, M. Thomas. Spenser and the Epithalamic convention. Comparative Literature. Vol. 9, No. 3. Duke University Press, 1957, 215-228. 
5. Kühlmann, Wilhelm. Neo-Latin Literature in Early Modern Germany. Early Modern German Literature 1350-1700. M. Reinhart (ed.). M., NY : Camden House, 2007, 281-330.

6. Mann, Nicholas. The Origins of Humanism. The Cambridge Companion to Renaissance Humanism, J. Kraye (ed.). Cambridge : Cambridge University Press, 2004, 1-19.

7. Munck, Thomas. Seventeenth-Century Europe: State, Conflict and Social Order in Europe 1598-1700. Second Edition. Houndmills : Macmillan International Higher Education, 2005.

8. Plantation P. Raising children in the early $17^{\text {th }}$ century: demographics. Pieejams: https:// www.plimoth.org/sites/default/files/media/pdf/edmaterials_demographics.pdf [skatīts 10.09.2018.]

9. Rubenis, Andris. Renesanses un reformācijas laikmeta kultūra Eiropā. Rīga : Zvaigzne ABC, 2000.

10. Scaliger, Julius Caesar. Poetices Libri Septem. [Geneva] : Petrus Santandreanus, 1594.

11. Tufte, Virginia. The Poetry of Marriage; the Epithalamium in Europe and its Development in England. Los Angeles : Tinnon-Brown, [1970].

\section{THE ADDRESSEES OF THE $17^{\text {TH }}$ CENTURY LATIN NUPTIAL POETRY IN RIGA}

\section{SUMMARY}

Soon after the Protestant Reformation took place in Livonia in the $16^{\text {th }}$ century, the currents of European humanism came to Livonia. In the $17^{\text {th }}$ century, occasional poetry appeared also in Riga as a result of historical and religious impact.

Literates living in Livonia congratulated their colleagues, family, friends and well known people in society by writing occasional poems. One of the most praised events in family life is wedding. For this event, the authors published small poetry books, encompassing at times several dozens of poems.

In the present paper, the preconditions for advent of Latin nuptial poetry in Riga in the $17^{\text {th }}$ century are disclosed. A particular focus is placed upon the analysis of some characteristic features of Latin nuptial poems written for the occasion of wedding and on the analysis of their distinctive characteristics on lexical level with a special attention to the basic characters such as bride and groom. 